\title{
HBV and HIV viral load but not microbial translocation or immune activation are associated with liver fibrosis among patients in South Africa
}

Tongai Gibson Maponga ${ }^{1 *}$ (D, Monique I. Andersson ${ }^{1,2}$, Christoffel J. van Rensburg 3 , Joop E. Arends ${ }^{4}$, Jantjie Taljaard ${ }^{5}$, Wolfgang Preiser ${ }^{1}$ and Richard H. Glashoff ${ }^{1,6}$

\begin{abstract}
Background: Co-infection with HIV negatively impacts the progression of chronic hepatitis B virus (HBV) infection, including causing rapid progression to liver fibrosis. Sub-Saharan Africa represents arguably the most important intersection of high endemicity of both chronic hepatitis B virus (HBV) infection and HIV infection.

Methods: We recruited $46 \mathrm{HBV} / \mathrm{HIV}$-co-infected; $47 \mathrm{HBV}$-monoinfected; $39 \mathrm{HIV}$-monoinfected; and $37 \mathrm{HBV} / \mathrm{HIV}$-uninfected patients from Tygerberg Hospital, Cape Town, South Africa. All HIV-infected patients were on antiretroviral therapy for $\geq 3$ months. Liver stiffness measurements were assessed using the Fibroscan (Fibroscan 402, Echosens). Cell-based immunomarkers were measured by flow cytometry. Soluble serum/plasma immunomarkers were measured by Luminex technology and enzyme immunoassays. HIV (COBAS/Ampliprep TaqMan HIV-1) and HBV viral loads (in-house assay) were also performed.

Results: HBV/HIV co-infected patients showed significantly higher levels of immune activation \%CD8+/HLA-DR+/CD38+ (median 30\%, interquartile range: 17-53) and \%CD8+/PD-1 (median 22\%, interquartile range: 15-33), $p \leq 0.01$ compared to all other study groups. Despite this, the HBV-mono-infected group had the highest proportion of patients with advanced liver fibrosis ( $\geq 13 \mathrm{kPa}$ ) as measured by Fibroscan (18\%). HBV mono-infected patients showed highest expression of most cytokines including IL-17 and basic fibroblastic growth factor. There was significant positive correlation between detectable HIV and HBV viral replication and liver fibrosis but not immune activation or gut translocation.

Discussion: Highly-active antiretroviral therapy, including tenofovir, is effective against both HIV and HBV. Earlier therapy in the co-infected patients may therefore have controlled viral replication leading to better fibrosis scores when compared to HBV mono-infection in this study. On-going HBV and HIV viraemia, rather than microbial translocation or immune activation, appear to be the drivers of liver fibrosis. Moderate to advanced liver fibrosis in HBV-mono-infection may well indicate poor access to screening and treatment of HBV infection.
\end{abstract}

Keywords: Hepatitis B infection, HIV, Transient elastography, Cytokines, Anti-retroviral treatment, Viraemia, Microbial translocation products

\footnotetext{
*Correspondence: tongai@sun.ac.za

Data presented previously in part at the 21st International AIDS Conference

(AIDS 2016) Durban, South Africa, 18-22 July 2016 and as part of Tongai

Maponga's PhD thesis deposited in the SUNScholar repository at

Stellenbosch University.

'Division of Medical Virology, Stellenbosch University Faculty of Medicine

and Health Sciences, Tygerberg, Cape Town, South Africa

Full list of author information is available at the end of the article
}

(c) The Author(s). 2018 Open Access This article is distributed under the terms of the Creative Commons Attribution 4.0 International License (http://creativecommons.org/licenses/by/4.0/), which permits unrestricted use, distribution, and reproduction in any medium, provided you give appropriate credit to the original author(s) and the source, provide a link to the Creative Commons license, and indicate if changes were made. The Creative Commons Public Domain Dedication waiver (http://creativecommons.org/publicdomain/zero/1.0/) applies to the data made available in this article, unless otherwise stated. 


\section{Background}

Sub-Saharan Africa represents arguably the most important intersection of high endemicity of both chronic hepatitis $B$ virus (HBV) infection and HIV infection. HIV infection has been reported to alter the natural history of $\mathrm{HBV}$ by increasing $\mathrm{HBV}$ replication rates leading to elevated hepatitis $\mathrm{B}$ viraemia, delaying seroconversion from $\mathrm{HBeAg}$ to anti-HBe and also hastening the development of liver fibrosis [1]. Findings from elsewhere have shown that patients co-infected with HIV and HBV present with rapidly progressive liver disease, have a higher risk of developing cirrhosis and an elevated risk of death from liver-related disease compared to those with either $\mathrm{HBV}$ or HIV infection alone [2-5].

Chronic HBV infection is associated with immune tolerance in the liver, particularly during the immune tolerance phase [6]. However, HBV/HIV co-infection may lead to the loss of immune tolerance. Acute HIV infection results in severe depletion of gut associated lymphoid tissue cells (primarily memory $\mathrm{T}$ lymphocytes), which is associated with epithelial damage and results in leakage of gut-derived microbial antigens into the systemic circulation. Consequently, individuals with HIV infection have significantly elevated systemic levels of microbial products compared to HIV-uninfected individuals [7]. Translocated microbial products cause immune activation and have been associated with hepatic fibrosis [8]. Increased serum LPS levels are associated with liver fibrosis progression from various aetiologies such as chronic misuse of alcohol and non-alcoholic steatohepatitis [9].

Within the liver environment, LPS binds to TLR-4 on Kupffer cells and hepatocytes [10]. The interaction of LPS with TLR-4 initiates secretion of proinflammatory and fibrogenic cytokines $[9,11,12]$. Several pro-inflammatory cytokines, such as IL-1 $\beta$, IL-6 and IFN- $\gamma$, have been associated with chronic inflammation in the liver environment and may be important in the relationship between inflammation and hepatocarcinogenesis [13]. The expression of these pro-inflammatory cytokines has been shown to increase with exposure to LPS while secretion of potentially protective anti-inflammatory cytokines such as IL-10 is reduced [13]. We explored the association between immune dysregulation caused by HIV infection and development of liver fibrosis in South African patients with or without HBV co-infection with the hypothesis that in patients with HIV/ HBV co-infection, HIV facilitates the development of liver fibrosis via immune activation in response to the leakage of gut microbial products into the systemic circulation.

\section{Methods}

\section{Study participants}

Ethics approval was obtained from the Health Research Ethics Committee at Stellenbosch University. HBV/HIV co-infected and HIV-mono-infected patients were recruited from the Infectious Diseases Clinic while HBV-monoinfected and HBV-/HIV-uninfected patients (controls) were enrolled among patients attending the Gastroenterology Clinic at Tygerberg Hospital, Cape Town following written informed consent. Patients with other known liver diseases or HCV infection were excluded from the study. Patients of age $<18$ years were also excluded. Epidemiological data as well as data on alcohol consumption and history of herbal medicine use were collected using a study-specific questionnaire.

\section{Non-invasive measurement of liver fibrosis and specimen collection}

Patients had liver stiffness measurements by transient elastometry (TE) using the Fibroscan 402 (Echosens, Paris, France). TE cut-off values of $<7 \mathrm{kPa}, 7.0-13.0$ and $\geq$ $13 \mathrm{kPa}$ were used to assign liver fibrosis severity as defined previously [14]. Blood was drawn for platelet count, aspartate transaminase (AST) and alanine transaminase (ALT) used to calculate the AST to platelet ratio index (APRI) and fibrosis-4 (FIB-4) scores. Aliquots of EDTA whole blood were also prepared for flow cytometric immune cell phenotyping.

\section{Virological and immunological testing}

Serum specimens of $\mathrm{HBV}$-infected patients were tested for $\mathrm{HBeAg}$ and antibodies to $\mathrm{HBeAg}$ (anti-HBe) using DiaSorin ETI-EBK PLUS and ETI-AB-EBKPLUS immunoassay kits (DiaSorin, Saluggia, Italy). HBV DNA testing was performed using an in-house quantitative PCR as previously described [15]. Samples with detectable HBV DNA were sequenced on the polymerase region of the HBV genome. HIV-1 viral loads were performed using the COBAS/Ampliprep TaqMan HIV-1 version 2.0 on the COBAS TaqMan Analyser (Roche Molecular Systems, CA). CD4 cell counts were performed on EDTA-anticoagulated blood using the BD TruCount on the BD FACSCalibur instrument (BD Biosciences, San Jose, CA).

\section{Flow cytometric measurement of \% CD8+ and CD4+ T-cells expressing CD38, HLA-DR, PD-1 and CTLA-4}

Two panels were designed; Immune Activation Panel and Immune Exhaustion Panel. The Immune Activation Panel consisted of the following fluorochrome-coupled monoclonal antibodies: CD3-FITC; CD4-ECD; CD8-PC-7; CD45-KO; CD38-PE and; HLA-DR-APC (Beckman Coulter, $\mathrm{MI})$. The Immune Exhaustion Panel was composed of CD3FITC; CD4-ECD; CD8-PC7; CD45-KO; CTLA-4-PE and; PD-1-APC. Flow cytometry data acquisition was performed using a Navios flow cytometer (Beckman Coulter). Optimal volatges for acquisition were determined, compensation and fluorescence minus one analyses were performed before testing of study samples. The gating strategy is shown in 
Additional file 1: Figure S1. Data analysis was performed using Beckman Coulter Kaluza software.

\section{Measurement of serum markers of microbial translocation and soluble cytokines}

Plasma soluble CD14 (sCD14) and lipoprotein binding protein (LBP) levels were measured as biomarkers of LPS activity by enzyme immunoassays using the Human sCD14 and the Human LBP ELISA kits (Hycult Biotech, Uden, Netherlands). Serum cytokines and chemokines were measured by Luminex technology using the premixed Bio-Plex pro Human Cytokine Grp 1 panel 27-plex (IL-1 $\beta$, IL-1ra, IL-2, IL-4, IL-5, IL-6, IL-7, IL-8, IL-9, IL-10, IL-12(p70), IL-13, IL-15, IL-17, basic FGF, eotaxin, G-CSF, GM-CSF, IFN- $\gamma$, IP-10, MCP-1, MIP- $1 \alpha$, MIP-1 $\beta$, PGDFBB, RANTES, TNF- $\alpha$ and VEGF) and the Bio-Plex Pro TGF- $\beta$ Panel 3-plex (TGF- $\beta$ 1, 2 and 3) assays (Bio-Rad Laboratories, CA). Acquisition was performed on the Bio Plex 200 platform (Bio Rad Laboratories).

\section{Statistical analysis}

Statistical analysis was carried out in Statistica version 12 (StatSoft, OK) and GraphPad Prism version 5 software (GraphPad Software, CA). Normality of data was tested using the D'Agostino-Pearson omnibus test. Non-parametric data was described using medians and interquartile ranges. Differences between groups were compared using the Mann-Whitney test where there were only two groups or the Kruskal-Wallis test in cases of three or more groups. Multiple comparisons were preformed using the Dunn's post-test where the Kruskal-Wallis $p$ value was significant. Data with normal distribution was described using means and $95 \%$ confidence intervals (95\% CI). Comparisons between groups (appearing as rows) were performed using the unpaired t-test when data was normally distributed. Categorical data was described using proportions and 95\% CI and the differences in observed frequencies across groups were analysed using the $\chi^{2}$ test (or Fisher's test when the number in a cell was low). Correlational analysis was performed using the Spearman rank correlation test. All hypothesis testing was done at 95\% confidence intervals and results were regarded as significant if $p<0.05$.

\section{Results}

\section{Demographics}

We recruited 169 patients into the study. The distribution of the patients was $46 \mathrm{HBV} / \mathrm{HIV}$ co-infected; $47 \mathrm{HBV}$ mono-infected; 39 HIV mono-infected and; $37 \mathrm{HBV} / \mathrm{HIV}$ uninfected controls attending the gastroenterology clinic (Table 1).

\section{Immunological and virological characteristics}

All co-infected and HIV mono-infected patients were on antiretroviraltherapy for $\geq 3$ months (Table 1). All HIV- infected patients (HBV/HIV co-infected and HIV monoinfected) were on tenofovir together with emtricitabine or lamivudine. HIV virological suppression was achieved by $30 / 36(78 \%)$ of co-infected compared to $27 / 33$ (82\%) of HIV mono-infected patients (Table 1). Only 12/47 (25\%) of HBV mono-infected patients were on antiviral therapy while the duration of therapy varied from one week to 24 months. Of the $12 \mathrm{HBV}$ patients receiving antiviral therapy, 11 were on tenofovir while a single patient was on lamivudine. The median CD4 cell count in the co-infected group was 328 cells/ $\mu \mathrm{l}, \mathrm{IQR}$ 242-562 compared to 528 cells/ $\mu$ l; IQR 367-657 in the HIV mono-infected group, $p=0.04$. HBV viral loads had significant negative correlation with duration of therapy among co-infected patients, rho $=-0.48 ; p<0.05$.

\section{Prevalence of liver fibrosis using non-invasive markers}

Due to the low number of HBV-mono-infected patients on therapy, statistical analysis was done taking the treated and untreated HBV mono-infected patients as a single group. The median of $\mathrm{TE}$ in the treated HBV mono-infected group was $7.2 \mathrm{kPa}$ (IQR: 5.3-13.0) compared to 7.3 (IQR: 5.7-8.8) in the untreated HBV mono-infected, $p=0.98$. Taken as a single group, the HBV mono-infected group had the highest proportion $7 / 38$ (18\%) of patients with TE values $\geq 13 \mathrm{kPa}$ compared to $4 / 36(11 \%)$ in the coinfected group and $3 / 32(9 \%)$ in the HIV monoinfected group. (Table 2). The proportion of patients with TE values between 7 and $13 \mathrm{kPa}$ was comparable between the co-infected and HBV-mono-infected groups at $11 / 36(31 \%)$ and $12 / 38$ (32\%), respectively. These proportions were higher than the 1/32 (3\%) and 6/29 (21\%) among HIV-monoinfected and controls, respectively.

\section{Microbial translocation markers}

The HBV/HIV group had median serum sCD14 concentration of $3.6 \mu \mathrm{g} / \mathrm{ml}$; IQR $2.4-6.2$ compared to $1.8 \mu \mathrm{g} /$ $\mathrm{ml}$; IQR $1.1-2.4$ in the HBV group, $2.4 \mu \mathrm{g} / \mathrm{ml}$; IQR $1.8-$ 4.3 in the HIV group and $1.6 \mu \mathrm{g} / \mathrm{ml}$; IQR $1.2-2.2$ in the control group, $p<0.0001$. Statistically significant differences in serum concentration were observed between co-infected compared to the HBV mono-infected $(p<0$. 0001); co-infected against the controls $(p<0.00001)$, HBV mono-infected versus HIV mono-infected $(p=0.02)$ and controls compared to HIV mono-infected $(p=0.0007)$ (Fig. 1). Serum LBP concentrations showed a trend toward increased levels in the co-infected group compared to the other groups, $p=0.06$ (Additional file 1: Table S1). There were no statistically significant differences in the serum concentration of microbial 
Table 1 Demographic, immunologic and virologic characteristics of study participants according to group

\begin{tabular}{|c|c|c|c|c|c|}
\hline & $\begin{array}{l}\mathrm{HBV} / \mathrm{HIV} \\
(n=46)\end{array}$ & $\begin{array}{l}\text { HBV } \\
(n=47)\end{array}$ & $\begin{array}{l}\text { HIV } \\
(n=39)\end{array}$ & $\begin{array}{l}\text { Controls } \\
(n=37)\end{array}$ & $p$ \\
\hline Age in years (mean \pm standard deviation) & $38.5 \pm 8.2$ & $37.9 \pm 12.3$ & $37.9 \pm 9.7$ & $43.8 \pm 11.4$ & 0.04 \\
\hline Males (\%) & $22(47 \%)$ & $22(47 \%)$ & $16(39 \%)$ & $25(41 \%)$ & 0.1 \\
\hline \multicolumn{6}{|l|}{ Ethnicity, n (\%) } \\
\hline African & $31(67 \%)$ & $18(38 \%)$ & $17(44 \%)$ & $5(14 \%)$ & \\
\hline Mixed & $14(32 \%)$ & $25(53 \%)$ & $22(56 \%)$ & $30(81 \%)$ & $0.0001^{\mathrm{b}}$ \\
\hline Caucasian & $1(1 \%)$ & $3(7 \%)$ & - & $2(5 \%)$ & \\
\hline Asian & - & $1(2 \%)$ & - & - & \\
\hline Body mass index & $24.3 \pm 5.1$ & $28.0 \pm 9.0$ & $24.6 \pm 3.5$ & $27.0 \pm 5.9$ & 0.2 \\
\hline Alcohol consumption & $8 / 46(17 \%)$ & $9 / 47(19 \%)$ & $11 / 39(28 \%)$ & $14 / 37(38 \%)$ & 0.1 \\
\hline Herbal medicine use (current/past) & $1 / 46(2 \%)$ & $5 / 47(11 \%)$ & $1 / 39(3 \%)$ & $5 / 37(14 \%)$ & 0.11 \\
\hline $\begin{array}{l}\text { ART, months } \\
\text { Median (IQR) }\end{array}$ & $36(23-63)$ & $\mathrm{n} / \mathrm{a}$ & $36(12-63)$ & $\mathrm{n} / \mathrm{a}$ & \\
\hline $\begin{array}{l}\text { CD4 count, (cells/ML) } \\
\text { Median (IQR) }\end{array}$ & $\begin{array}{l}328 \\
(242-562)\end{array}$ & $\begin{array}{l}922 \\
(647-1297)\end{array}$ & $\begin{array}{l}528 \\
(367-657)\end{array}$ & $\begin{array}{l}1031 \\
(790-1215)\end{array}$ & $<0.0001$ \\
\hline $\begin{array}{l}\text { CD4/CD8 ratio } \\
\text { Median (IQR) }\end{array}$ & $0.5(0.3-0.7)$ & $1.5(1.1-2.1)$ & $0.7(0.6-1.0)$ & $1.6(1.3-2.1)$ & $<0.0001$ \\
\hline CD4 nadir & $256(144-369)$ & & $281(169-440)$ & & 0.2 \\
\hline Detectable plasma HIV-1 viral load & 10/36 (27.8\%) & $\mathrm{n} / \mathrm{a}$ & $6 / 33(18.1 \%)$ & $\mathrm{n} / \mathrm{a}$ & 0.4 \\
\hline HIV-1 viral load > 1000 copies $/ \mathrm{ml}^{\mathrm{a}}$ & $6 / 36(17 \%)$ & $\mathrm{n} / \mathrm{a}$ & $3 / 33(9.1 \%)$ & $\mathrm{n} / \mathrm{a}$ & 0.5 \\
\hline Detectable plasma HBV DNA & $22 / 45(49 \%)$ & $32 / 44(73 \%)$ & $\mathrm{n} / \mathrm{a}$ & $\mathrm{n} / \mathrm{a}$ & 0.03 \\
\hline Plasma HBV DNA > $2000 \mathrm{IU} / \mathrm{ml}^{c}$ & $12 / 45(26 \%)$ & $15 / 44(32 \%)$ & $\mathrm{n} / \mathrm{a}$ & $\mathrm{n} / \mathrm{a}$ & 0.5 \\
\hline HBeAg positive, (\%) & $13 / 46(28 \%)$ & $6 / 46(13 \%)$ & $\mathrm{n} / \mathrm{a}$ & $\mathrm{n} / \mathrm{a}$ & 0.1 \\
\hline
\end{tabular}

${ }^{\mathrm{a}} 1000$ copies/ml chosen for HIV-1 viral load as this defines virological failure in patients on ART

${ }^{b}$ Indicates where a chi test was used for statistical analysis

${ }^{\mathrm{C}} \mathrm{HBV}$ DNA $>2000 \mathrm{IU} / \mathrm{ml}$ cut-off used as it may indicate the need for therapy in some patients

translocation markers between the treated and untreated HBV mono-infected patients (data not shown).

\section{Expression of CD38, HLA-DR, PD-1 and CTLA-4 on CD4+ and CD8+ T lymphocytes}

There were no significant differences in the expression of cell-associated immune markers between the treated and untreated HBV mono-infected groups and as a result were considered as a single group for statistical analysis. The median percentage CD8+/CD38 +/HLA-DR+ co-expression in HBV/HIV co-infected patients was $30 \%$; IQR $17-53$ compared to $23 \%$; IQR 16-33 in the HIV mono-infected group, 17\%; IQR $14-22$ in the HBV mono-infected and 16\%; IQR $8-26$ in the control group $(p<0.0001)$ (Table 3$)$. The expression of PD-1 on both CD4+ and CD8+ T lymphocytes was also highest amongst co-infected patients compared to all other groups, $p<0.0001$ in each instance. Post-test analysis showed that $\%$ CD8+/PD-1 was significantly higher among co-infected patients compared to HBV mono-infected and controls. Percentage CD4+/PD-1+ was significantly higher in the co-infected group (median
22; IQR 15-33) and HIV mono-infected (22; IQR 15-26) compared to HBV mono-infected (13.2; IQR 11-20) and controls (15; IQR 9-21). The HIV mono-infected group had higher \%CD4+/PD-1+ compared to the control group (Table 3).

\section{Detection of serum cytokines}

Within the HBV mono-infected group, only PDGF was statistically significantly different in concentration between the treated and untreated patients with the treated having median $3.84 \mathrm{ng} / \mathrm{ml}$ (IQR: 3.28-4.78) compared to $2.97 \mathrm{ng} / \mathrm{ml}$ (IQR: $1.81-3.57$ ) among untreated patients, $p=0.04$. We therefore considered the treated and untreated HBV mono-infected patients as a single group for multigroup comparison. Levels of basic fibroblast growth factor, IL-9 and IL-17 were particularly elevated in the HBV mono-infected group (Table 4). Serum levels of IP-10 were high among co-infected patients. TGF-beta isotypes were highly expressed in the HIV-mono-infected group. Analysis of serum cytokine concentrations was also performed excluding the control group significance levels (shown as p2 in Table 4). 
Table 2 Summary and distribution of fibrosis results according to group

\begin{tabular}{|c|c|c|c|c|c|}
\hline & HBV/HIV & HBV & HIV & Controls & $p$ \\
\hline Valid Fibroscan & $36 / 40(90 \%)$ & 38/41 (93\%) & $32 / 37(86 \%)$ & 29/30 (97\%) & 0.5 \\
\hline Fibroscan (kPa) & $n=36$ & $\mathrm{n}=38$ & $n=32$ & $n=29$ & \\
\hline$<7.0$ & $21(58 \%)$ & $19(50 \%)$ & $28(88 \%)$ & $23(79 \%)$ & \\
\hline 7.0-13 & $11(31 \%)$ & $12(32 \%)$ & $1(3 \%)$ & $6(21 \%)$ & $0.002^{b}$ \\
\hline$\geq 13$ & $4(11 \%)$ & $7(18 \%)$ & $3(9 \%)$ & - & \\
\hline APRI & $n=43$ & $n=35$ & $n=26$ & $n=22$ & \\
\hline$<0.5$ & 31 (72\%) & 25 (71\%) & $21(81 \%)$ & 19 (86\%) & \\
\hline $0.5-1.5$ & $9(21 \%)$ & $7(20 \%)$ & $4(15 \%)$ & $3(14 \%)$ & $0.8^{b}$ \\
\hline$>1.5$ & $3(7 \%)$ & $3(9 \%)$ & $1(4 \%)$ & - & \\
\hline FIB-4 & $n=42$ & $n=34$ & $n=26$ & $n=22$ & \\
\hline$<1.30$ & 31 (74\%) & 27 (79\%) & 19 (73\%) & 20 (91\%) & \\
\hline $1.30-3.25$ & $9(21 \%)$ & $4(12 \%)$ & $7(27 \%)$ & $2(9 \%)$ & $0.32^{b}$ \\
\hline$>3.25$ & $2(5 \%)$ & $3(9 \%)$ & - & - & \\
\hline$A L T, U / L^{a}$ & $34(24-45)$ & $25(22-47)$ & $31(21-44)$ & 24 (19-39) & 0.3 \\
\hline AST, U/L $L^{a}$ & $31(25-46)$ & $27(23-42)$ & $32(27-45)$ & $21(18-32)$ & 0.001 \\
\hline Fibroscan, $\mathrm{kPa}^{\mathrm{a}}$ & $6.2(4.8-8.0)$ & $6.9(5.5-8.8)$ & $4.7(3.9-5.9)$ & $5.6(4.6-6.8)$ & 0.001 \\
\hline$\left.A P R\right|^{a}$ & $0.32(0.24-0.58)$ & $0.34(0.21-0.66)$ & $0.32(0.23-0.46)$ & $0.21(0.13-0.42)$ & 0.08 \\
\hline $\mathrm{FIB}-4^{\mathrm{a}}$ & $0.96(0.58-1.30)$ & $0.86(0.59-1.20)$ & $0.77(0.55-1.30)$ & $0.63(0.41-1.00)$ & 0.1 \\
\hline
\end{tabular}

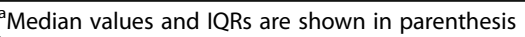

${ }^{\mathrm{b}}$ Indicates where a chi test was used

The data in bold are entries where there were zero observations for the particular cell

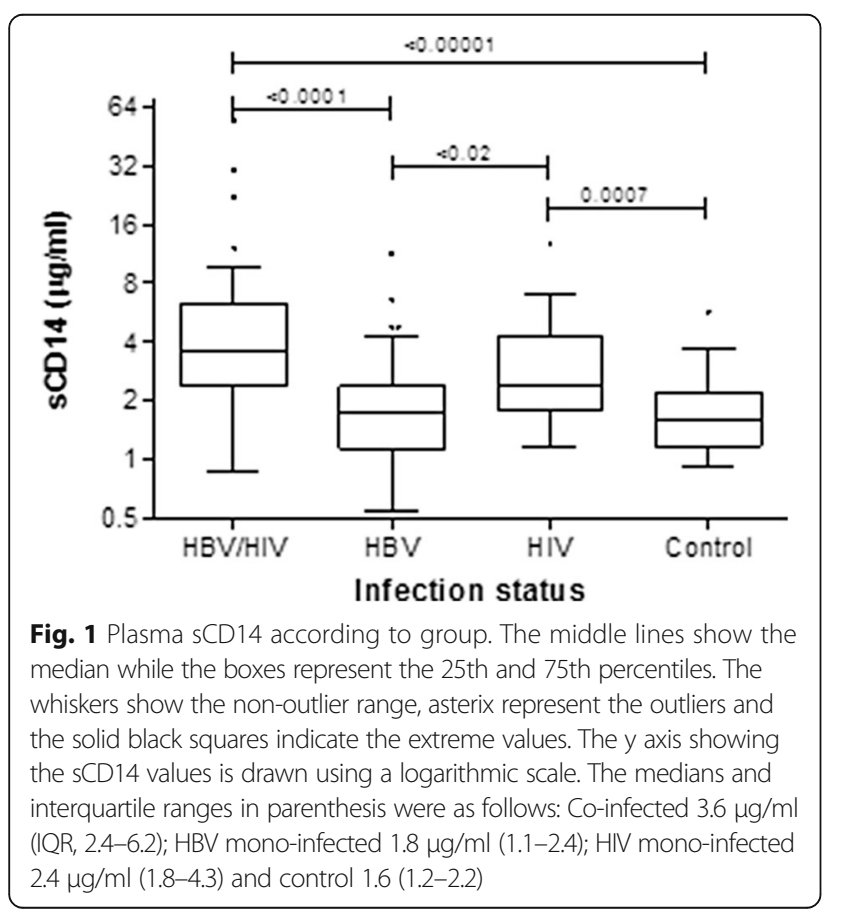

Correlation was analysed for all study participants as a single group as well as according to their infection status using all continuous variables measured in the study. There were significant positive correlations between IP-10 and sCD14 (rho $=0.32 ; p=0.00008)$ and IP-10 with LBP (rho $=0.19 ; p=0.02$ ). IP-10 was also positively correlated with HIV viral load (rho $=0.42 ; p$ $=0.004$ ) and HBV viral load (rho $=0.37, p=0.02$ ) in the co-infected group. Principle component analysis of serum cytokine concentrations showed relatively good distinction between HBV mono-infected, HBV/HIV coinfected patients from the HIV mono-infected and controls. There was poor distinction between the HIV mono-infected participants and controls (Fig. 2).

\section{Correlation of viral and immune markers with non- invasive tests of liver fibrosis}

Correlation was performed for all participants without stratification of groups and according to the individual groups. In the ungrouped analyses, median stiffness had significant positive correlation with HIV viral load (rho $=0.29, p=0.02$ ) and HBV viral load (rho $=0.30, p=0.007$ ). In addition, HBV viral load was significantly correlated with APRI score within the HBV mono-infected group (rho $=0.5, p=0.003$ ). Soluble CD14 positively correlated with $\% \mathrm{CD} 8+/ \mathrm{CD} 38$ 
Table 3 Expression of cell-surface expressed markers on CD4+ and CD8+ T lymphocytes

\begin{tabular}{|c|c|c|c|c|c|}
\hline & Co-infected & HBV Mono & HIV Mono & Control & $p$ \\
\hline$\%$ CD4/CD38+/HLA-DR+ & $9.9(6.2-17)$ & $4.7(3.6-6.3)$ & $7(4.5-12)$ & $3.5(2.6-6)$ & $<0.0001$ \\
\hline$\% C D 8 / C D 38+/ H L A-D R+$ & $30(17-53)$ & $17(14-22)$ & $23(16-33)$ & $16(7.7-26)$ & $<0.0001$ \\
\hline$\% C D 4+/ P D-1+$ & $25(18-34)$ & $18(13-23)$ & $21(15-27)$ & $13(8-22)$ & $<0.0001$ \\
\hline$\% C D 8+/ P D-1+$ & $22(15-33)$ & $13.2(11-20)$ & $22(15-26)$ & $15(9-21)$ & $<0.0001$ \\
\hline
\end{tabular}

Median and IQR (in parenthesis) are shown. Values are percentages of either CD4+ or CD8+ T cells expressing marker of interest

+ HLA-DR+ (rho $=0.19, p=0.01)$ and also percentage CD8+/PD-1+ expression (rho $=0.2, p=0.009$ ). Soluble CD14 showed significant negative correlation to CD4 $+\mathrm{T}$ cell count $(\mathrm{rho}=-0.04, p<0.0001)$ and $\mathrm{CD} 4 / \mathrm{CD} 8$ ratio (rho $=-0.5, p<0.00001$ ) (Additional file 1: Table
S3). HIV viral loads positively correlated with CD8 $+/$ CD38+/HLA-DR+ expression within the co-infected group (rho $=0.4, p<0.05$ ) but not in the HIV monoinfected (Additional file 1: Figure S2). We did not observe any statistically significant correlations between

Table 4 Median plasma cytokine concentrations

\begin{tabular}{|c|c|c|c|c|c|c|c|c|}
\hline & Units & LDL & $\mathrm{HBV} / \mathrm{HIV}, n=45$ & $\mathrm{HBV}, n=44$ & $\mathrm{HIV}, n=39$ & Control, $n=19$ & $\mathrm{p}$ & p2 \\
\hline$\overline{I L-1 \beta}$ & $\mathrm{pg} / \mathrm{ml}$ & 0.47 & $1.3(0.9-2.8)$ & $2(1.5-3.1)$ & $1.2(0.9-1.9)$ & $1.7(1.2-2.8)$ & 0.001 & 0.0004 \\
\hline IL-1ra & $\mathrm{pg} / \mathrm{ml}$ & 5.33 & $59(40.4-100.8)$ & $110.8(85.1-376.7)$ & $62.2(40.4-85.8)$ & $69.8(53.7-106.3)$ & $<0.00001$ & $<0.00001$ \\
\hline IL-2 & $\mathrm{pg} / \mathrm{ml}$ & 1.52 & $0(0-5.4)$ & $8(0.5-18.4)$ & $0(0-7.3)$ & $0(0-4.7)$ & 0.0002 & 0.0002 \\
\hline $\mid \mathrm{L}-4$ & $\mathrm{pg} / \mathrm{ml}$ & 0.24 & $2.2(1.6-3)$ & $2.8(2.1-4.1)$ & $2.2(1.6-3.2)$ & $2.3(2-2.9)$ & 0.03 & 0.02 \\
\hline $\mid L-5^{\mathrm{a}}$ & $\mathrm{pg} / \mathrm{ml}$ & 1.00 & $0(0-7)$ & $0(0-15.5)$ & $0(0-0)$ & $0(0-4)$ & $n / a$ & $n / a$ \\
\hline IL-6 & $\mathrm{pg} / \mathrm{ml}$ & 1.68 & $10(0.8-18.3)$ & $11.3(7.2-29.3)$ & $4.3(0.5-10.3)$ & $6.3(1.5-12.5)$ & 0.002 & 0.005 \\
\hline IL-7 & $\mathrm{pg} / \mathrm{ml}$ & 0.84 & $9(3.7-14.6)$ & $7.4(2.5-14.8)$ & $1.2(0-7.9)$ & $5.9(1.2-9)$ & 0.002 & 0.001 \\
\hline IL-8 & $\mathrm{pg} / \mathrm{ml}$ & 2.44 & $26.8(19.5-53.3)$ & $51.9(22.8-121.8)$ & $21.7(13.9-43.6)$ & $120.1(35.2-437.2)$ & $<0.00001$ & 0.002 \\
\hline IL-9 & $\mathrm{pg} / \mathrm{ml}$ & 1.19 & $54.7(44.5-73.8)$ & $73.1(55.6-118.5)$ & $59.5(45.5-83.7)$ & $78.2(57.6-97.1)$ & 0.01 & 0.02 \\
\hline IL-10 & $\mathrm{pg} / \mathrm{ml}$ & 2.21 & $10.2(5.8-18.8)$ & $15.9(11.3-29.2)$ & $9.5(5.6-14.5)$ & $9.7(7.7-15.9)$ & 0.001 & 0.005 \\
\hline IL-12 & $\mathrm{pg} / \mathrm{ml}$ & 2.25 & $50.8(31.9-63.6)$ & $47.4(27.1-87.9)$ & $35.2(19.4-59.9)$ & $44.5(31.7-65.4)$ & 0.3 & 0.2 \\
\hline IL-13 & $\mathrm{pg} / \mathrm{ml}$ & 0.40 & $12(6.2-24.8)$ & $13.8(8-29.6)$ & $9.5(5.2-13.7)$ & $6.5(4.8-10.4)$ & 0.004 & 0.02 \\
\hline $\mid \mathrm{L}-15^{\mathrm{a}}$ & $\mathrm{pg} / \mathrm{ml}$ & 5.73 & $0(0-0)$ & $0(0-0)$ & $0(0-0)$ & $0(0-0)$ & $n / a$ & \\
\hline IL-17 & $\mathrm{pg} / \mathrm{ml}$ & 5.81 & $44.5(27.7-84.3)$ & $81.7(61.6-133.2)$ & $67.7(54.1-111.9)$ & $78.5(64.1-110.4)$ & 0.004 & 0.006 \\
\hline EOTAXIN & $\mathrm{pg} / \mathrm{ml}$ & 1.75 & $107.9(81.2-172.8)$ & $129.3(72.1-171.3)$ & $115.8(73.9-160.1)$ & $142.5(93.1-261.1)$ & 0.4 & 0.8 \\
\hline Basic-FGF & $\mathrm{pg} / \mathrm{ml}$ & 3.91 & $43.1(21.8-66.9)$ & $65.7(46.2-92.3)$ & $44.8(24.2-61.3)$ & $50.4(34.2-65.7)$ & 0.0006 & 0.0002 \\
\hline G-CSF & $\mathrm{pg} / \mathrm{ml}$ & 3.06 & $51.1(32.1-66.1)$ & $59.7(44.1-98.6)$ & $41.9(30.3-58.1)$ & $37.6(32.1-66.1)$ & 0.006 & 0.004 \\
\hline GM-CSF & $\mathrm{pg} / \mathrm{ml}$ & 2.9 & $0(0-22.2)$ & $25.5(0-87.6)$ & $0(0-35.7)$ & $0.6(0-15.3)$ & 0.006 & 0.003 \\
\hline IFN- $\gamma$ & $\mathrm{pg} / \mathrm{ml}$ & 42.9 & $88.7(57.5-145.3)$ & $121.2(80.1-182.0)$ & $66.7(48-125.7)$ & $97.2(51.1-116.7)$ & 0.004 & 0.004 \\
\hline IP-10 & $\mathrm{ng} / \mathrm{ml}$ & 4.94 & $1.5(1.0-2.8)$ & $0.9(0.7-1.5)$ & $1.1(0.8-1.5)$ & $1(0.8-1.2)$ & 0.0001 & 0.0001 \\
\hline MCP-1 & $\mathrm{pg} / \mathrm{ml}$ & 1.24 & $4.7(0-27.2)$ & $21.3(0-54.4)$ & $0.4(0-20.5)$ & $17.3(0-78.8)$ & 0.03 & 0.2 \\
\hline MIP-1a & $\mathrm{pg} / \mathrm{ml}$ & 0.15 & $4.4(1.3-7.7)$ & $7.3(4.6-11.4)$ & $4.7(2.5-6.3)$ & $8.2(5.3-10.3)$ & 0.001 & 0.006 \\
\hline PDGF & $\mathrm{ng} / \mathrm{ml}$ & 1.00 & $2.4(1.7-3.3)$ & $3.2(1.8-3.9)$ & $2.9(1.9-3.8)$ & $3.3(2.3-4.5)$ & 0.09 & 0.2 \\
\hline MIP-1b & $\mathrm{pg} / \mathrm{ml}$ & 0.46 & $140.9(95.5-218.8)$ & 147.3 (102.7-199.1) & $128.8(103.8-227.4)$ & $217(155.5-264.7)$ & 0.06 & 0.9 \\
\hline RANTES & $\mathrm{ng} / \mathrm{ml}$ & 3.72 & $19.9(16.7-26.7)$ & $19.0(13.8-23.1)$ & $19.1(16.7-22.6)$ & $22.1(17.8-24.7)$ & 0.2 & 0.3 \\
\hline TNF-a & $\mathrm{pg} / \mathrm{ml}$ & 3.77 & $19.5(15.1-27.4)$ & $23.5(18.5-54.5)$ & $19.5(15-24)$ & $18.5(15.1-26.2)$ & 0.01 & 0.007 \\
\hline VEGF & $\mathrm{pg} / \mathrm{ml}$ & 2.30 & $88.9(52.2-147.7)$ & $117.7(60-211.5)$ & $77.8(45.2-138)$ & $89.6(51.5-160.5)$ & 0.2 & 0.09 \\
\hline TGF- $\beta 1$ & $\mathrm{ng} / \mathrm{ml}$ & & $41.7(34.1-53.6)$ & $46.4(38.3-56.8)$ & $49.7(42.1-55.7)$ & $48.2(42.5-55)$ & 0.10 & 0.06 \\
\hline TGF- $\beta 2$ & $\mathrm{ng} / \mathrm{ml}$ & & $1.8(1.7-1.9)$ & $2.1(1.8-2.4)$ & $2.3(1.8-2.5)$ & $2(1.7-2.4)$ & $<0.00001$ & $<0.00001$ \\
\hline TGF- $\beta 3$ & $\mathrm{ng} / \mathrm{ml}$ & & $1.3(1.2-1.5)$ & $1.9(1.4-2.2)$ & $2.2(1.5-2.3)$ & $1.8(1.4-2.2)$ & $<0.00001$ & $<0.00001$ \\
\hline
\end{tabular}

aplasma levels of IL-5 and IL-15 were below detection limit in most samples across the groups hence the medians of 0 pg/ml. Column heading p2 shows the level of significance of Kruskal-Wallis test excluding the control group 


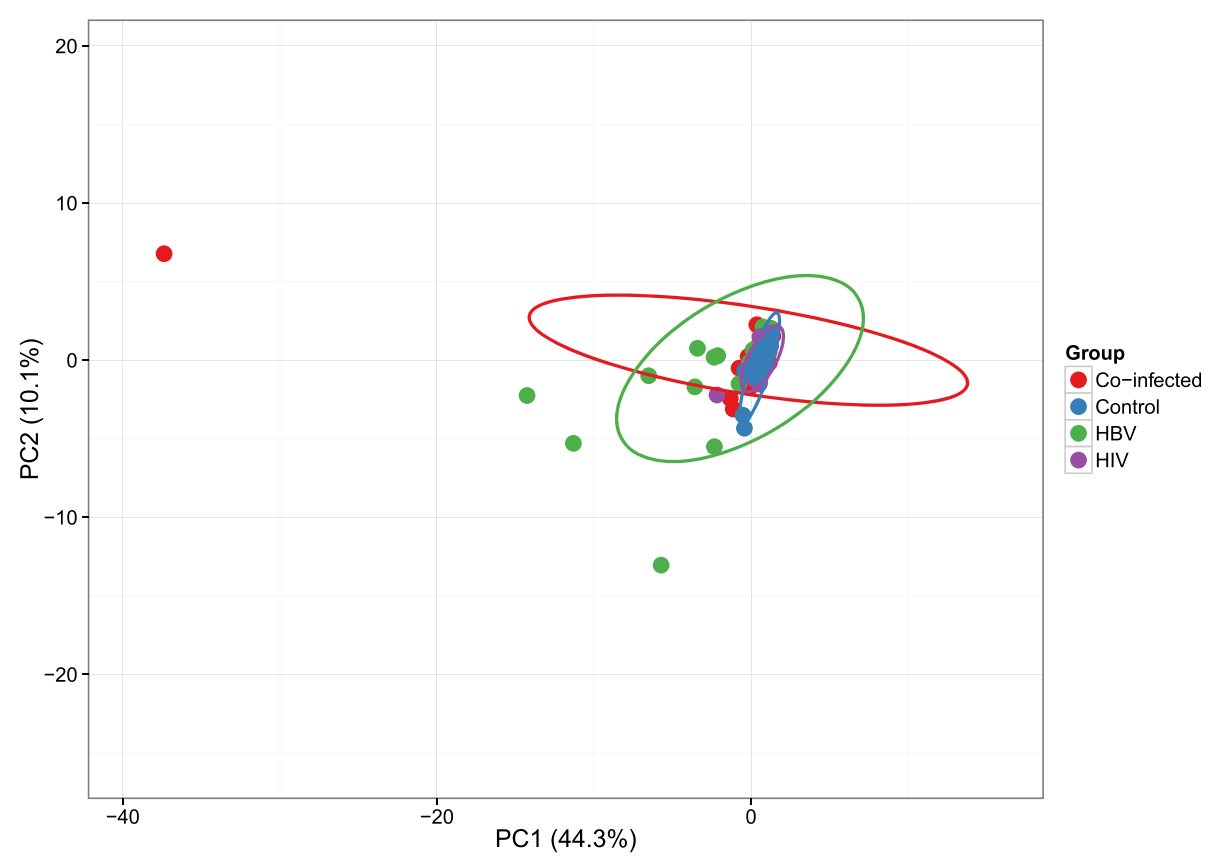

Fig. 2 Principle component analysis of plasma concentrations of microbial translocation markers and cytokines. The plot shoes serum cytokine signatures of the four patients groups. The prediction ellipses represent 0.95 probability that a new observation from the same group will fall inside area. The ellipses for the co-infected and HBV groups appear to be distinct from those of the HIV mono-infected and control groups. The $x$ and y-axis show principal component 1 and principal component 2 that explain $44.3 \%$ and $10.1 \%$ of the total variance observed, respectively

cytokine levels and liver stiffness except for IL-5 (rho $=0$. $17, p=0.049$ ), TGF- $\beta 2$ (rho $=-0.26, p=0.003$ ), TGF- $\beta 2$ $($ rho $=-0.31, p<0.001)$ and TGF- $\beta 3$ (rho $=-0.31, p$ $<0.001$ ) (Additional file 1: Table S3).

\section{Molecular characterization of HBV and association with liver fibrosis}

Of 22 viraemic co-infected patients, 13 (59.1\%) were successfully sequenced compared to 29/32 (90.6\%) of HBV mono-infected participants (Additional file 1: Figure S3). The medians of the TE scores for the different genotypes were $7.9 \mathrm{kPa}$; IQR $5.8-12.1$ for genotype A $(n=21)$, $6.3 \mathrm{kPa}$;QR $5.8-7.6$ for genotype $\mathrm{D}(n=11)$ and $7.0 \mathrm{kPa}$; IQR 5.3-7.9 for genotype $\mathrm{E}(n=4)$. There was no statistically significant difference in TE scores according to the HBV genotype, $p=0.43$ (Additional file 1: Table S2). No classic mutations associated with resistance to nucleotide reverse transcriptase inhibitors were observed in the coinfected or HBV mono-infected group.

\section{Discussion}

HIV co-infection has an adverse impact on the natural progression of hepatitis $\mathrm{B}$ [16]. On the contrary, data describing the effect of hepatitis B on HIV infection is limited. Despite being on ART, co-infected patients had lower CD4 cell counts compared to those infected with HIV alone. The proportion of patients with plasma HIV viral load > 1000 copies $/ \mathrm{ml}$ was also higher among those with co-infection (17\%) compared to those with HIV alone $(9 \%)$ as shown in Table 2. This may also explain the low CD4 cell counts among co-infected patients as negative correlation was observed between HIV viral load and CD4 cell counts. We did not have the data on the CD4 counts before these patients were started on ART but other studies have shown that HBV/HIV co-infected individuals have lower CD4 counts or impaired CD4 cell count recovery compared to those with resolved $\mathrm{HBV}$ infection and HBV-uninfected patients independent of duration of ART [4, 17-19]. Data on nadir CD4 counts in this study showed no statistically significant differences between the co-infected and HIV mono-infected groups. Reasons for the decreased immune recovery include upregulation of apoptotic pathways in co-infection and sequestration of lymphocytes within the spleen following HBV-driven liver fibrosis $[19,20]$. Low CD4/CD8 ratios despite effective ART are associated with continuous immune dysregulation, immune senescence and are predictive of non-AIDS morbidity and mortality [21]. Our results show co-infected patients with significantly lower median CD4/CD8 ratio compared to those infected with HIV alone which is explained by the fact that normalisation of CD4/CD8 ratio is solely based on the recovery of CD4 cells.

HBV mono-infected patients more frequently had detectable HBV DNA compared to the co-infected patients; ( $49 \%$ vs $73 \%, p=0.03$ ). This is expected as not all the HBV mono-infected patients were on therapy. The 
presence of HBV DNA among the co-infected patients who were on effective therapy may indicate non-adherence to therapy. Another reason may be that HBV DNA load on therapy is a function of time because of the significant negative correlation observed between time on therapy and HBV viraemia. A study of Zambian and South African patients reported that only $15 / 21$ (71\%) of co-infected patients achieved HBV suppression after a year of tenofovir plus lamivudine or emtricitabine [22]. However, not all HBV-infected patients on therapy will achieve virologic suppression even without obvious drug-resistance mutations, especially those with high levels of replication such as in HIV co-infection and those that are HBeAg positive have delayed viral suppression [23-25]. The higher prevalence of HBeAg among co-infected patients compared to HBV mono-infected patients is a well-recognised effect of HIV infection [16, 26-28]. Even with administration of an effective regimen such as tenofovir plus emtricitabine, not all patients will achieve HBeAg seroconversion. A previous study reported that after 5 years of continuous therapy HBeAg seroconversion was achieved by only $57 \%$ of HIV/ HBV co-infected patients [29].

Our results of TE showed that the HBV mono-infected group had the highest proportion of patients with significant or advanced fibrosis and the highest the median of TE value compared to all other groups. The results showing a higher proportion of patients with significant fibrosis among those with HBV/HIV coinfection compared to HIV mono-infected patients are consistent with findings from other groups where coinfection was associated with higher TE values [30-32]. HIV alone independently increases liver fibrosis progression rates [33, 34]. However, the finding of a higher proportion of $\mathrm{HBV}$ mono-infected individuals with advanced fibrosis compared to HIV mono-infected is not unexpected because the majority of HBV mono-infected patients in this cohort were not on treatment. Treatment of hepatitis B improves liver fibrosis and this probably explains the reason for lower TE values in the co-infected patients compared to those with HBV mono-infection [35].

Soluble CD14 is a marker of monocyte/macrophage activation that is normally induced by exposure to LPS. The results from this study showed that co-infected patients had the highest plasma SCD14 levels compared to those infected with either HBV or HIV alone. Research in paediatric and adult patients infected with HIV has shown that despite ART, there is persistently higher immune activation punctuated by elevated levels of SCD14 and that this is not related to HIV viraemia [36, 37]. Our results also support these findings because plasma sCD14 did not correlate with either plasma HBV DNA or HIV RNA, thus supporting the idea that gut microbial translocation is independent of on-treatment viral load. This may explain why no difference was detected in microbial translocation markers between HBV mono-infected patients that were on therapy and those that were not. A potential mechanism for continued monocyte activation may be due to blunted recovery of CD4 T cells during ART [38]. However, this study cannot determine the rate of $\mathrm{CD} 4 \mathrm{~T}$ cell recovery of the HIVinfected patients that were recruited because of its crosssectional design. ART does not restore gut integrity and therefore continued elevations of LBP and sCD14 are expected [39, 40]. The overall finding from the microbial translocation markers and liver fibrosis markers would seem to suggest that gut translocation is not associated with liver stiffness in this treated cohort. Instead, according to the results of the ungrouped analysis viral replication is the driver of liver fibrosis.

Co-infected patients displayed the highest percentage of CD4+ and CD8+ T lymphocytes co-expressing HLA-DR and CD38 compared to other groups in this study. The results suggest that HIV infection is the driver of immune activation because of the positive correlation between HIV viraemia and CD8/CD38/HLA-DR expression. Significant positive correlation was observed in the ungrouped analysis and the co-infected group. Interestingly, there was no correlation between the expression of peripheral blood cell-based immune markers of activation and liver stiffness as measured by any of the fibrosis markers. This may be due to the fact that the study measured immune activation in peripheral blood and not the hepatic environment. Research on the hepatic environment in HBV/HIV coinfected patients previously found no evidence of increased inflammation but rather apoptosis as the driver of liver fibrosis [41]. The elevated serum concentrations of IL-9, IL-17 and fibrogenic basic fibroblast growth factor in plasma of HBV mono-infected patients support recent reports highlighting the roles of these biomarkers in pathogenesis of liver fibrosis due to viral hepatitis [42-45]. The co-infected group had significantly higher levels of IP-10 compared to the HBV mono-infected group. Increased IP-10 levels could be an indicator of continued immune activation from viral replication and gut translocation in HBV/HIV co-infection and have been described as remaining elevated in co-infected patients despite combination antiretroviral therapy [46].

Our study hypothesis was that in co-infection with HIV and HBV, HIV facilitates the development of liver fibrosis via immune activation in response to the leakage of gut microbial products into the systemic circulation. Instead, we found that although there was increased microbial translocation shown by increased sCD14 and elevated immune dysregulation in HBV/HIV co-infected patients, the proportion of patients with moderate/advanced liver fibrosis as determined by TE was higher in the HBV mono-infected group compared to those with co-infection. The finding of no significant correlation between microbial translocation markers and liver fibrosis scores would seem to imply that microbial products are not the driver of 
fibrosis but rather viral replication. This is because TE had significant positive correlation with both HIV and HBV viraemia in the ungrouped analysis. The relationship of active viral replication with fibrosis implicates active antigen-specific anti-viral responses as being important to pathogenesis of liver fibrosis. Viral replication as the driver of liver fibrosis has been reported among treatmentnaïve $\mathrm{HBV} / \mathrm{HIV}$ co-infected patients in Zambia and Switzerland [47].

There are some limitations in this study. The sample size of treated and untreated HBV mono-infected patients was too small to consider them as separate groups, which would have been ideal. The small number of HBV mono-infected patients on therapy is a reflection of the lack of prioritization of therapy for HBV infections in South Africa. The nonavailability of liver biopsies from study participants makes it difficult to validate the accuracy of the results of the noninvasive tests for fibrosis although the use of Fibroscan has been validated in numerous studies in the past $[48,49]$. Valid TE measurements were not obtained on all patients due to visceral obesity and unavailability of a large probe. An effect of other undiagnosed infections on expression of markers of immune activation cannot be eliminated although any patients with overt symptoms of other infectious diseases were excluded. Another limitation is that the assessment of immune markers was not virusspecific. This study did not measure microbial components such as LPS or microbial 16S rRNA per se but rather products of the host physiologic response to microbial translocation. We measured LBP and SCD14 in this current study because LPS has a short half-life in circulation and its measurement using the widely utilized Limulus assay is subject to interference from other molecules in the blood where it may be bound to serum binding proteins [50]. Other studies have shown strong correlation between LPS levels and sCD14 and/or LBP [50,51]. The effect of previously described single nucleotide polymorphisms of the CD14 gene on the expression of sCD14 was not explored in this study but variations in the gene could potentially influence the long-term recovery of $\mathrm{CD} 4 \mathrm{~T}$ cells in HIVinfected patients on HAART [52]. Nevertheless, the data from this study is important to the process of developing prospective studies to monitor prognosis of HBV infection, especially among HBV-mono-infected patients who are under-diagnosed and under-treated.

\section{Conclusions}

The findings suggest that HBV-mono-infected patients in this study have worse liver fibrosis than patients with HBV/HIV co-infection despite immune activation being higher in the latter group. HBV/HIV co-infected patients in South Africa have better access to screening, effective treatment and monitoring than those that are HBV-monoinfected. There is a need for screening for HBV infection and monitoring of HBV mono-infected patients to allow initiation of timely and effective interventions in order to prevent the development of complications such as advanced liver fibrosis and/or hepatocellular carcinoma.

\section{Additional file}

\begin{abstract}
Additional file 1: Table S1. Serum LPB concentration according to patient group ( $\mu \mathrm{g} / \mathrm{ml})$. Table S2. Proportions of fibrosis scores according to the HBV genotype. Table S3. Multiple correlation analysis of all patients ungrouped. Statistically significant correlations appear in red font. Figure S1. Gating strategy for Immune Activation panel. Plot A shows the singlet population gating while Plot B represents the SSC against FSC plot indicating the position of the singlet cells of the lymphocyte population. Plot $C$ shows the lymphocyte population as shown by less complexity (SS) and intense staining for CD45-KO in a plot of side scatter against CD45-KO. Plot D shows the CD3+ population (Gate G) as gated from Gate $\mathrm{F}$ shown in Plot $\mathrm{C}$. Using colour precedence and back gating, Plot D also shows the non-lymphocyte population (red colour) that is included within gate $F$ based on use of complexity (SS INT) and staining for CD45. Picture E shows the CD4+ in the blue colour (gate H) and the CD8+ lymphocytes in the magenta colour (gate I). Plot F shows the CD8+ population staining for CD38-PE and HLA-DR-APC gated from gate I. The gate placement was based on defined fluorescence minus one (FMO) settings. Figure S2. Scatter plot of \% CD8/CD38+/HLA-DR+ in the co-infected group. The plot only includes HBV/HIV co-infected patients. All patients with undetectable HIV viral load are assigned values of zero and appear on the $y$-axis as dots corresponding with the percentage expression CD8/CD38+/HLA-DR. Frequency of HBV genotypes according to HBV and HIV infection status. Among the 13 co-infected patients whose HBV was successfully sequenced, 8 (62\%) were infected with HBV genotype A, 3 (23\%) with D and 2 had HBV genotype $E$ (15\%). The distribution of genotypes among the HBV mono-infected patients was- 16/29 (55\%) A, 11/29 (38\%) D and 2/29 (7\%) E. The red columns represent HBV genotype A, green is for genotype $D$ and the blue corresponds to genotype E. Genotyping was frequently more successful in the HBV mono-infected group compared to the co-infected group. (DOCX $475 \mathrm{~kb})$
\end{abstract}

\section{Acknowledgements}

We thank the clinical officers and nursing staff in the Infectious Diseases Clinic and the Gastroenterology Clinic at Stellenbosch University for assistance with blood collection from study participants. We also thank Professor Andy Hoepelman from the Department of Internal Medicine and Infectious Disease, University Medical Center Utrecht (UMCU), Utrecht, The Netherlands for the kind donation of the Fibroscan.

\section{Funding}

The research described in this report was supported by the Poliomyelitis Research Foundation (13/09), the South African National Health Laboratory Services Research Trust (004-94518) and the Harry Crossley Foundation. The content is solely the responsibility of the authors and does not necessarily represent the official views of the funders.

\section{Availability of data and materials}

The data that support the findings of this study are available at Stellenbosch University and may be obtained from the authors upon reasonable request.

\section{Authors' contributions}

TGM, MIA, WP and RHG developed the research question; TGM, MIA, JEA, CJVR and JT recruited patients and collected data. TGM, MIA, WP and RHG contributed to the data analysis. TGM, MIA, CJVR, JEA, JT, WP and RHG wrote the manuscript. All authors read and approved the final manuscript draft.

Ethics approval and consent to participate

Participants were recruited following written informed consent according to the Declaration of Helsinki 2008. Ethical approval for the study was obtained from the health research ethics committee at Stellenbosch University (S13/04/072). 


\section{Competing interests}

The authors declare that they have no competing interests.

\section{Publisher's Note}

Springer Nature remains neutral with regard to jurisdictional claims in published maps and institutional affiliations.

\section{Author details}

'Division of Medical Virology, Stellenbosch University Faculty of Medicine and Health Sciences, Tygerberg, Cape Town, South Africa. ${ }^{2}$ Oxford University Hospitals NHS Foundation Trust, Oxford, United Kingdom. ${ }^{3}$ Division of Gastroenterology, Stellenbosch University Faculty of Medicine and Health Sciences, Tygeberg, Cape Town, South Africa. ${ }^{4}$ Department of Internal Medicine, Section Infectious Diseases, University Medical Center Utrecht (UMCU), Utrecht University, Utrecht, The Netherlands. ${ }^{5}$ Division of Infectious Diseases, Stellenbosch University Faculty of Medicine and Health Sciences, Tygerberg, Cape Town, South Africa. ${ }^{6}$ Division of Medical Microbiology \& Immunology, Stellenbosch University Faculty of Medicine and Health Sciences \& National Health Laboratory Service, Tygerberg, Cape Town, South Africa.

Received: 5 January 2018 Accepted: 25 April 2018 Published online: 08 May 2018

\section{References}

1. Thio CL. Hepatitis B and human immunodeficiency virus coinfection. Hepatology. 2009:49(S5):S138-45.

2. Thio CL, Seaberg EC, Skolasky R Jr, Phair J, Visscher B, Munoz A, Thomas DL, Multicenter ACS. HIV-1, hepatitis B virus, and risk of liver-related mortality in the multicenter cohort study (MACS). Lancet. 2002;360(9349):1921-6.

3. Colin JF, Cazals-Hatem D, Loriot MA, Martinot-Peignoux M, Pham BN, Auperin A, Degott C, Benhamou JP, Erlinger S, Valla D, et al. Influence of human immunodeficiency virus infection on chronic hepatitis $B$ in homosexual men. Hepatology. 1999;29(4):1306-10.

4. Konopnicki D, Mocroft A, de Wit S, Antunes F, Ledergerber B, Katlama C, Zilmer K, Vella S, Kirk O, Lundgren JD, et al. Hepatitis B and HIV: prevalence, AIDS progression, response to highly active antiretroviral therapy and increased mortality in the EuroSIDA cohort. AIDS. 2005;19(6):593-601.

5. Hoffmann CJ, Seaberg EC, Young S, Witt MD, D'Acunto K, Phair J, Thio CL. Hepatitis B and long-term HIV outcomes in coinfected HAART recipients. AIDS. 2009;23(14):1881-9.

6. Tran T. Immune tolerant hepatitis B: a clinical dilemma. Gastroenterol Hepatol (N Y). 2011;7(8):511-6.

7. Brenchley JM, Price DA, Schacker TW, Asher TE, Silvestri G, Rao S, Kazzaz Z, Bornstein E, Lambotte O, Altmann D, et al. Microbial translocation is a cause of systemic immune activation in chronic HIV infection. Nat Med. 2006; 12(12):1365-71.

8. Sandler NG, Koh C, Roque A, Eccleston JL, Siegel RB, Demino M, Kleiner DE, Deeks SG, Liang TJ, Heller T, et al. Host response to translocated microbial products predicts outcomes of patients with HBV or HCV infection. Gastroenterology. 2011;141(4):1220-30. 1230 e1221-1223.

9. Crane M, Visvanathan K, Lewin SR. HIV infection and TLR Signalling in the liver. Gastroenterol Res Pract. 2012;2012:473925.

10. Mimura Y, Sakisaka S, Harada M, Sata M, Tanikawa K. Role of hepatocytes in direct clearance of lipopolysaccharide in rats. Gastroenterology. 1995;109(6):1969-76.

11. Tilton JC, Johnson AJ, Luskin MR, Manion MM, Yang J, Adelsberger JW Lempicki RA, Hallahan CW, McLaughlin M, Mican JM, et al. Diminished production of monocyte proinflammatory cytokines during human immunodeficiency virus viremia is mediated by type I interferons. J Virol. 2006;80(23):11486-97.

12. Chow JC, Young DW, Golenbock DT, Christ WJ, Gusovsky F. Toll-like receptor-4 mediates lipopolysaccharide-induced signal transduction. J Biol Chem. 1999;274(16):10689-92.

13. Budhu A, Wang XW. The role of cytokines in hepatocellular carcinoma. J Leukoc Biol. 2006;80(6):1197-213.

14. Marcellin P, Ziol M, Bedossa P, Douvin C, Poupon R, de Ledinghen V, Beaugrand M. Non-invasive assessment of liver fibrosis by stiffness measurement in patients with chronic hepatitis B. Liver Int. 2009:29(2):242-7.

15. Garson JA, Grant PR, Ayliffe U, Ferns RB, Tedder RS. Real-time PCR quantitation of hepatitis $B$ virus DNA using automated sample preparation and murine cytomegalovirus internal control. J Virol Methods. 2005;126(1-2):207-13.
16. Hoffmann CJ, Thio CL. Clinical implications of HIV and hepatitis B co-infection in Asia and Africa. Lancet Infect Dis. 2007:7(6):402-9.

17. Hoffmann CJ, Charalambous S, Martin DJ, Innes C, Churchyard GJ, Chaisson $\mathrm{RE}$, Grant AD, Fielding KL, Thio CL. Hepatitis B virus infection and response to antiretroviral therapy (ART) in a south African ART program. Clin Infect Dis. 2008:47(11):1479-85.

18. Idoko J, Meloni S, Muazu M, Nimzing L, Badung B, Hawkins C, Sankale JL, Ekong E, Murphy R, Kanki P, et al. Impact of hepatitis B virus infection on human immunodeficiency virus response to antiretroviral therapy in Nigeria. Clin Infect Dis. 2009;49(8):1268-73.

19. Wandeler G, Gsponer T, Bihl F, Bernasconi E, Cavassini M, Kovari H, Schmid $P$, Battegay M, Calmy A, Egger $M$, et al. Hepatitis B virus infection is associated with impaired immunological recovery during antiretroviral therapy in the Swiss HIV cohort study. J Infect Dis. 2013;208(9):1454-8.

20. Nebbia G, Peppa D, Schurich A, Khanna P, Singh HD, Cheng Y, Rosenberg W, Dusheiko G, Gilson R, ChinAleong J, et al. Upregulation of the Tim-3/ galectin-9 pathway of T cell exhaustion in chronic hepatitis B virus infection PLOS One. 2012;7(10):e47648.

21. Lu W, Mehraj V, Vyboh K, Cao W, Li T, Routy JP. CD4:CD8 ratio as a frontier marker for clinical outcome, immune dysfunction and viral reservoir size in virologically suppressed HIV-positive patients. J Int AIDS Soc. 2015:18:20052.

22. Hamers RL, Zaaijer HL, Wallis CL, Siwale M, Ive P, Botes ME, Sigaloff KC, Hoepelman Al, Stevens WS, Rinke de Wit TF, et al. HIV-HBV coinfection in southern Africa and the effect of lamivudine- versus tenofovir-containing CART on HBV outcomes. J Acquir Immune Defic Syndr. 2013;64(2):174-82.

23. Huang AJ, Nunez M. Outcomes in HIV/HBV-Coinfected patients in the Tenofovir era are greatly affected by immune suppression. J Int Assoc Provid AIDS Care. 2015;14(4):360-8.

24. Marcellin P, Heathcote EJ, Buti M, Gane E, de Man RA, Krastev Z, Germanidis G, Lee SS, Flisiak R, Kaita K, et al. Tenofovir Disoproxil fumarate versus Adefovir Dipivoxil for chronic hepatitis B. N Engl J Med. 2008;359(23):2442-55.

25. Thio CL, Smeaton L, Hollabaugh K, Saulynas M, Hwang H, Saravanan S, Kulkarni S, Hakim J, Nyirenda M, lqbal HS, et al. Comparison of HBV-active HAART regimens in an HIV-HBV multinational cohort: outcomes through 144 weeks. AIDS. 2015;29(10):1173-82.

26. Andersson MI, Maponga TG, ljaz S, Barnes J, Theron GB, Meredith SA, Preiser W, Tedder RS. The epidemiology of hepatitis B virus infection in HIVinfected and HIV-uninfected pregnant women in the western cape, South Africa. Vaccine. 2013:31(47):5579-84.

27. Di Bisceglie AM, Maskew M, Schulze D, Reyneke A, McNamara L, Firnhaber C. HIV-HBV coinfection among south African patients receiving antiretroviral therapy. Antivir Ther. 2010;15(3 Pt B):499-503.

28. Oshitani H, Kasolo FC, Mpabalwani M, Mizuta K, Luo NP, Suzuki H, Numazaki $Y$. Prevalence of hepatitis $B$ antigens in human immunodeficiency virus type 1 seropositive and seronegative pregnant women in Zambia. Trans R Soc Trop Med Hyg. 1996;90(3):235-6.

29. Kosi L, Reiberger T, Payer BA, Grabmeier-Pfistershammer K, Strassl R, Riege A, Peck-Radosavljevic M. Five-year on-treatment efficacy of lamivudine-, tenofovir- and tenofovir + emtricitabine-based HAART in HBV-HIVcoinfected patients. J Viral Hepat. 2012;19(11):801-10.

30. Hawkins C, Agbaji O, Ugoagwu P, Thio CL, Auwal MM, Ani C, Okafo C, Wallender E, Murphy RL. Assessment of liver fibrosis by transient Elastography in patients with HIV and hepatitis B virus coinfection in Nigeria. Clin Infect Dis. 2013;57(12):e189-92.

31. Stabinski L, Reynolds SJ, Ocama P, Laeyendecker O, Ndyanabo A, Kiggundu V, Boaz I, Gray RH, Wawer M, Thio C, et al. High prevalence of liver fibrosis associated with HIV infection: a study in rural Rakai, Uganda. Antivir Ther. 2011;16(3):405-11.

32. Castellares C, Barreiro P, Martin-Carbonero L, Labarga P, Vispo ME, Casado R, Galindo L, Garcia-Gasco P, Garcia-Samaniego J, Soriano V. Liver cirrhosis in HIV-infected patients: prevalence, aetiology and clinical outcome. J Viral Hepat. 2008;15(3):165-72.

33. Vlahakis SR, Villasis-Keever A, Gomez TS, Bren GD, Paya CV. Human immunodeficiency virus-induced apoptosis of human hepatocytes via CXCR4. J Infect Dis. 2003;188(10):1455-60

34. Tuyama AC, Hong F, Saiman Y, Wang C, Ozkok D, Mosoian A, Chen P, Chen BK, Klotman ME, Bansal MB. Human immunodeficiency virus (HIV)-1 infects human hepatic stellate cells and promotes collagen I and monocyte chemoattractant protein-1 expression: implications for the pathogenesis of HIV/hepatitis C virus-induced liver fibrosis. Hepatology. 2010:52(2):612-22 
35. Marcellin P, Gane E, Buti M, Afdhal N, Sievert W, Jacobson IM, Washington MK, Germanidis G, Flaherty JF, Aguilar Schall R, et al. Regression of cirrhosis during treatment with tenofovir disoproxil fumarate for chronic hepatitis B: a 5-year open-label follow-up study. Lancet. 2013;381(9865):468-75.

36. Wallet MA, Buford TW, Joseph AM, Sankuratri M, Leeuwenburgh C, Pahor M, Manini T, Sleasman JW, Goodenow MM. Increased inflammation but similar physical composition and function in older-aged, HIV-1 infected subjects. BMC Immunol. 2015;16:43.

37. Wallet MA, Rodriguez CA, Yin L, Saporta S, Chinratanapisit S, Hou W, Sleasman JW, Goodenow MM. Microbial translocation induces persistent macrophage activation unrelated to HIV-1 levels or T-cell activation following therapy. AIDS. 2010;24(9):1281-90.

38. Dunham RM, Vujkovic-Cvijin I, Yukl SA, Broadhurst MJ, Loke P, Albright RG, Wong JK, Lederman MM, Somsouk M, Hunt PW, et al. Discordance between peripheral and colonic markers of inflammation during suppressive ART. J Acquir Immune Defic Syndr. 2014;65(2):133-41.

39. Wada NI, Jacobson LP, Margolick JB, Breen EC, Macatangay B, Penugonda S, Martinez-Maza O, Bream JH. The effect of HAART-induced HIV suppression on circulating markers of inflammation and immune activation. AIDS. 2015; 29(4):463-71.

40. Chen J, Shao J, Cai R, Shen Y, Zhang R, Liu L, Qi T, Lu H. Anti-retroviral therapy decreases but does not normalize indoleamine 2,3-dioxygenase activity in HIV-infected patients. PLoS One. 2014;9(7):e100446.

41. Iser DM, Avihingsanon A, Wisedopas N, Thompson AJ, Boyd A, Matthews GV, Locarnini SA, Slavin J, Desmond PV, Lewin SR. Increased intrahepatic apoptosis but reduced immune activation in HIV-HBV co-infected patients with advanced immunosuppression. AIDS. 2011;25(2):197-205.

42. Qin SY, Lu DH, Guo XY, Luo W, Hu BL, Huang XL, Chen M, Wang JX, Ma SJ, Yang XW, et al. A deleterious role for Th9/L-9 in hepatic fibrogenesis. Sci Rep. 2016;6:18694.

43. Sun HQ, Zhang JY, Zhang H, Zou ZS, Wang FS, Jia JH. Increased Th17 cells contribute to disease progression in patients with HBV-associated liver cirrhosis. J Viral Hepat. 2012;19(6):396-403.

44. Jimenez-Sousa MA, Almansa R, de la Fuente C, Caro-Paton A, Ruiz L, Sanchez-Antolin G, Gonzalez JM, Aller R, Alcaide N, Largo P, et al. Increased Th1, Th17 and pro-fibrotic responses in hepatitis C-infected patients are down-regulated after 12 weeks of treatment with pegylated interferon plus ribavirin. Eur Cytokine Netw. 2010;21(2):84-91.

45. Jin-no K, Tanimizu M, Hyodo I, Kurimoto F, Yamashita T. Plasma level of basic fibroblast growth factor increases with progression of chronic liver disease. J Gastroenterol. 1997;32(1):119-21.

46. Crane $M$, Avihingsanon A, Rajasuriar R, Velayudham P, Iser D, Solomon A, Sebolao B, Tran A, Spelman T, Matthews G, et al. Lipopolysaccharide, immune activation, and liver abnormalities in HIV/hepatitis B virus (HBV)coinfected individuals receiving HBV-active combination antiretroviral therapy. J Infect Dis. 2014;210(5):745-51.

47. Wandeler G, Mulenga L, Vinikoor MJ, Kovari H, Battegay M, Calmy A, Cavassini M, Bernasconi E, Schmid P, Bolton-Moore C, et al. Liver fibrosis in treatment-naive HIV-infected and HIV/HBV co-infected patients: Zambia and Switzerland compared. Int J Infect Dis. 2016;51:97-102.

48. Bonnard P, Sombie R, Lescure FX, Bougouma A, Guiard-Schmid JB, Poynard T, Cales P, Housset C, Callard P, Le Pendeven C, et al. Comparison of elastography, serum marker scores, and histology for the assessment of liver fibrosis in hepatitis B virus (HBV)-infected patients in Burkina Faso. Am J Trop Med Hyg. 2010;82(3):454-8.

49. Mbaye PS, Sarr A, Sire J-M, Evra M-L, Ba A, Daveiga J, Diallo A, Fall F, Chartier $L$, Simon $F$, et al. Liver stiffness measurement and biochemical markers in Senegalese chronic hepatitis B patients with normal ALT and high viral load. PLoS One. 2011;6(7):e22291.

50. Abad-Fernandez M, Vallejo A, Hernandez-Novoa B, Diaz L, Gutierrez C, Madrid N, Munoz MA, Moreno S. Correlation between different methods to measure microbial translocation and its association with immune activation in long-term suppressed HIV-1-infected individuals. J Acquir Immune Defic Syndr. 2013;64(2):149-53.

51. Gonzalez-Quintela A, Alonso M, Campos J, Vizcaino L, Loidi L, Gude F. Determinants of serum concentrations of lipopolysaccharide-binding protein (LBP) in the adult population: the role of obesity. PLoS One. 2013;8(1):e54600.

52. Yong YK, Shankar EM, Solomon A, Spelman T, Fairley CK, Elliott JH, Hoy J, Cameron PU, Kamarulzaman A, Lewin SR. Polymorphisms in the CD14 and TLR4 genes independently predict CD4+ T-cell recovery in HIV-infected individuals on antiretroviral therapy. AIDS. 2016;30(14):2159-68.

\section{Ready to submit your research? Choose BMC and benefit from:}

- fast, convenient online submission

- thorough peer review by experienced researchers in your field

- rapid publication on acceptance

- support for research data, including large and complex data types

- gold Open Access which fosters wider collaboration and increased citations

- maximum visibility for your research: over $100 \mathrm{M}$ website views per year

At $B M C$, research is always in progress.

Learn more biomedcentral.com/submissions 